\title{
Effect of Petroleum-Derived Substances and their Bioremediation on Triticum aestivum L. Growth and Chemical Composition
}

\author{
Janina Gospodarek ${ }^{1 *}$, Milena Rusin ${ }^{1}$, Aleksandra Nadgórska-Socha ${ }^{2}$ \\ ${ }^{1}$ Department of Agricultural Environment Protection, University of Agriculture, Krakow, Poland \\ ${ }^{2}$ Department of Ecology, University of Silesia, Katowice, Poland
}

Received: 15 February 2018

Accepted: 29 May 2018

\begin{abstract}
The aim of our studies was to determine the follow-up (four years after the soil contamination) effect of petroleum derived substances (PDSs), e.g., spent engine oil (EO), diesel fuel (DF), and petrol (P) on the growth of winter wheat (Triticum aestivum L.) and on the content of nutrients and heavy metals in plant leaves. We also evaluated the supportive effect of bioremediation by the use of ZB-01 biopreparation upon the parameters mentioned above. In general, the studied PDSs had not affected the growth of winter wheat, which is indicative of its relative resistance toward this kind of contaminant. PDSs significantly modified the contents of some nutrients in plant leaves: soil contamination with DF resulted in a decrease in sulphur content, but contamination with $\mathrm{P}$ led to the increase in carbon content with a simultaneous decrease in iron content in the analysed organs of plants. Furthermore, oils contributed to the increase in the manganese content in plants. The contaminants used in the experiments contributed to the increases in the contents of such heavy metals, i.e., zinc, lead, cadmium, and copper in the leaves of winter wheat; nevertheless, this phenomenon depended on the kind of PDSs, with stronger effects caused by oils. The application of ZB-01 biopreparation on soil contaminated with PDSs evoked changeable effects depending on the kind of contaminant and the analysed parameter. It generally resulted in levelling the negative effects of EO and DF.
\end{abstract}

Keywords: petroleum-derived substances, macronutrients, heavy metals, bioremediation

\section{Introduction}

Petroleum and petroleum-derived substances (PDSs) contribute to the degradation of the soil environment and water ecosystems $[1,2]$. It follows from this fact

*e-mail: rrjgospo@cyf-kr.edu.pl that they contain a mixture of organic compounds with low bioavailability in their composition, often described as being carcinogenic and mutagenic [3, 4]. Those compounds cause essential changes in biological parameters such as enzymatic activity, and the numbers of micro- and macroorganisms in soil [5-8]. Furthermore, they show negative effects on the growth and development of plants growing on contaminated 
soil $[9,10]$ and modify the content of nutrients and heavy metals in plants [11]. For this reason, it becomes necessary to attempt the restoration of equilibrium in soil by adding various substances to the soil, bioremediation, phytoremediation, or applying more costly ex-situ methods [12].

Bioremediation is one of the most effective methods of cleaning soil from petroleum-derived substances, allowing for significant degradation of petroleumderived hydrocarbons [13]. The method uses specialized strains of microorganisms capable of decomposing toxic substances to those which are less dangerous or neutral toward the soil environment $[14,15]$. It is a relatively low-cost method, because it allows the cleaning process to take place in the same place where the contamination occurred $[16,17]$.

The aims of the studies included the following: (a) to determine the follow-up effect of petroleum derived substances (PDSs), e.g., spent engine oil (EO), diesel fuel (DF), and petrol (P) on the growth of winter wheat and on the content of nutrients and heavy metals in plant leaves; and (b) to evaluate the supportive effect of bioremediation by the use of ZB-01 biopreparation upon the parameters mentioned above.

\section{Material and Methods}

The field study area was in the Experimental Station of the University of Agriculture in Krakow, located in Mydlniki near Krakow, Poland $\left(50.0815^{\circ} \mathrm{N}\right.$, $\left.19.84730^{\circ} \mathrm{E}\right)$. In November 2009, indigenous soil

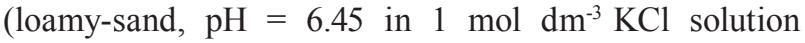
and 7.12 in water, organic carbon content $=1.04 \%$, $\mathrm{Pb}$ content $=25.5 \mathrm{mg} \mathrm{kg}^{-1}, \mathrm{Cd}$ content $=0.99 \mathrm{mg} \mathrm{kg}^{-1}$, $\mathrm{Ni}$ content $=2.19 \mathrm{mg} \mathrm{kg}^{-1}, \mathrm{Zn}$ content $=51.7 \mathrm{mg} \mathrm{kg}^{-1}$, $\mathrm{Cu}$ content $=5.02 \mathrm{mg} \mathrm{kg}^{-1}$, cation exchange capacity: $\mathrm{Ca}=0.0371 \mathrm{~mol} \mathrm{~kg}^{-1}, \mathrm{Mg}=0.0037 \mathrm{~mol} \mathrm{~kg}^{-1}, \mathrm{~K}=0.0033$

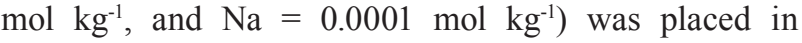
special containers of $1 \mathrm{~m}^{3}$ volume, retaining the natural arrangement of layers. The containers were sunk in the ground so that their upper edge was at the same level as the surface of the soil. In June 2010 the soil surface was artificially contaminated with petrol (P), used engine oil (EO), and diesel oil (DF) in a quantity of $6000 \mathrm{mg}$ of petroleum-derived substance per $1 \mathrm{~kg}$ of dry mass (i.e., typical petroleum concentration in medium-contaminated soils), by pouring it on the soil. The dose was calculated in relation to the total volume of the soil in the container. Petrol and diesel fuel came from a BP petrol station while engine oil was obtained from an Orlen station. Engine oil was used for one year (in a petrol engine) prior to application in this experiment. After one week, half of the number of containers were subjected to the bioremediation process by adding biopreparation ZB-01, which was specially produced for this experiment and contained selected prokaryotic organisms - mainly bacteria from the following genera: Pseudomonas, Moraxella,
Acinetobacter, Oligella, Alcaligenes, Methylobacterium, Bacillus, Stenotrophomonas, Corynebacterium, and Morganella. The decomposition activity of the proposed ZB-01 microbial consortium toward organic and aromatic petroleum-derived contaminants was confirmed in environmental practice [18-20]. After one year, i.e., in spring 2011, the bioremediation treatment was repeated according to the same procedure as in 2010. The non-contaminated soil was placed in identical containers and constituted the control treatment. (A detailed description of the process of setting the experiment and the containers used was included in an earlier publication [21]). The experiment was set in four replications in line with the randomized blocks method. In three subsequent years, the soil in the containers was left without any intervention to enable natural plant succession.

In the 2013 season, broad beans of the Windsor White variety were cultivated on the soil in containers. The data pertaining to the effect of polluted soil on the growth and chemical composition of that plant has already been published [21]. In mid-October 2013 the seeds of the winter wheat of the Batuta variety were sown in the soils in containers in the quantities of 400 seeds per container (in line with the standard for sowing seeds) after earlier soil preparation (i.e., loosening and fertilizing). The pre-sowing fertilization with Azofoska fertilizer was applied, adding to soil $5.44 \mathrm{~g} \mathrm{~N}, 2.56 \mathrm{~g}$ $\mathrm{P}_{2} \mathrm{O}_{5}$, and 7,64 $\mathrm{g} \mathrm{K}_{2} \mathrm{O}$ per container (the dose was set in line with the recommendation from the producer). In all objects, approximately $90 \%$ of wheat plants survived winter. The assessment of the morphology of plants and yield structure was done at the stage of the full grain maturity of winter wheat. In 15 randomly selected plants from each container, the following parameters were determined: the length of straw, the length of ear, the number of grains in each ear, the mass of 1000 grains, and grain yield.

In order to determine the concentrations of macro and microelements in the leaves of plants, plant material was cleaned of any patches of deposited aphid honeydew and other surface contaminants, washed in tap and then distilled water, and then dried at $105^{\circ} \mathrm{C}$. A portion of $0.25 \mathrm{~g}$ dried plant material was digested with $5 \mathrm{ml}$ of $\mathrm{HNO}_{3}$ at $120^{\circ} \mathrm{C}$ and then diluted to $25 \mathrm{ml}$ with deionized water. Next, the metal content was measured using flame absorption spectrometry (Thermo Scientific iCE 3500) [22, 23]. The carbon, nitrogen, and sulphur contents were determined in a Variomax CNS analyser. After completion of the experiment the analysis of the experimental soil was done in the WESSLING Poland Laboratory in Krakow. It confirmed that in four years after the contamination incident the content of PDSs in the contaminated soils was still much higher than in control soil (details in another paper that is at press).

The obtained results were then subjected to analysis by STATISTICA 10.0 software. The significance of differences between the means were tested by two-factor 
Table 1. Effects of petroleum-derived substances on selected morphological parameters of plants and yields.

\begin{tabular}{|c|c|c|c|c|c|}
\hline Treatments & $\begin{array}{c}\text { Length of straw } \\
(\mathrm{cm})\end{array}$ & $\begin{array}{c}\text { Length of ear } \\
(\mathrm{cm})\end{array}$ & $\begin{array}{c}\text { Number of grains in ear } \\
(\mathrm{pcs})\end{array}$ & $\begin{array}{c}\text { Mass of } 1000 \text { grains } \\
(\mathrm{g})\end{array}$ & $\begin{array}{c}\text { Grain yield } \\
\left(\mathrm{g} \mathrm{m}^{-2}\right)\end{array}$ \\
\hline EO & $51.87^{\mathrm{a}^{\mathrm{a}}}$ & $8.43^{\mathrm{bc}}$ & $39.05^{\mathrm{ab}}$ & $50.25^{\mathrm{a}}$ & $395.03^{\mathrm{ab}}$ \\
\hline EOr & $53.02^{\mathrm{abc}}$ & $7.78^{\mathrm{a}}$ & $37.13^{\mathrm{a}}$ & $50.92^{\mathrm{a}}$ & $336.06^{\mathrm{a}}$ \\
\hline DF & $52.63^{\mathrm{ab}}$ & $8.40^{\mathrm{bc}}$ & $39.25^{\mathrm{ab}}$ & $50.58^{\mathrm{a}}$ & $353.94^{\mathrm{ab}}$ \\
\hline $\mathrm{DFr}$ & $55.65^{\mathrm{c}}$ & $8.03^{\mathrm{ab}}$ & $39.00^{\mathrm{ab}}$ & $51.44^{\mathrm{a}}$ & $416.37^{\mathrm{ab}}$ \\
\hline P & $55.60^{\mathrm{c}}$ & $8.45^{\mathrm{bc}}$ & $43.03^{\mathrm{b}}$ & $51.13^{\mathrm{a}}$ & $470.89^{\mathrm{ab}}$ \\
\hline Pr & $60.67^{\mathrm{d}}$ & $8.88^{\mathrm{c}}$ & $43.00^{\mathrm{b}}$ & $50.59^{\mathrm{a}}$ & $510.48^{\mathrm{b}}$ \\
\hline$C$ & $54.77^{\mathrm{bc}}$ & $8.93^{\mathrm{cd}}$ & $40.93^{\mathrm{ab}}$ & $51.67^{\mathrm{a}}$ & $449.12^{\mathrm{ab}}$ \\
\hline$C r$ & $55.25^{\mathrm{bc}}$ & $9.48^{\mathrm{d}}$ & $41.58^{\mathrm{ab}}$ & $50.48^{\mathrm{a}}$ & $472.71^{\mathrm{ab}}$ \\
\hline
\end{tabular}

EO - soil contaminated with engine oil, DF - soil contaminated with diesel fuel, $\mathrm{P}$ - soil contaminated with petrol, C - control soil, $\mathrm{r}$ - with bioremediation

*Values marked by different letters are statistically different $(\alpha=0.05)$

variance analysis, and the means were differentiated by Fisher's LSD test at $\alpha=0.05$.

\section{Results and Discussion}

In four years after the contamination incident, the plants growing on soil contaminated by engine oil were significantly lower than both the control plants and those growing on soil contaminated with petrol (Table 1). In these plants, the length of straw was nearly $4 \mathrm{~cm}$ less than in control plants. Applying ZB-01 biopreparation in the object contaminated by petrol resulted in the increased straw length by more than $5 \mathrm{~cm}$ compared with the objects where biopreparation was not applied. A significant increase in straw length was also noted under the effect of supported bioremediation used on soil contaminated by diesel fuel (increase by approximately $3 \mathrm{~cm}$ ). Viewing that from another angle, however, it can be seen that the plants from objects contaminated with engine oil, after the biopreparation was applied, had lower length of ears (by $0.65 \mathrm{~cm}$ ). Neither significant effects of the PDSs applied, nor of the bioremediation process, were noted in terms of the number of grains per ear and of the mass of 1000 grains. Also absent were the statistically proven differences in the yield of grains between the plants exposed to contamination and the control plants. The obtained results thus indicate the remarkable resistance of winter wheat on the studied contaminants. Although the majority of results emphasize the adverse effects of PDSs upon the growth and development of cultivated plants [24-27], some studies confirm the resistance of cereals to that type of soil-derived contaminant [28]. Everything depends on the dose of the contaminant, its type, and the time that passes from when contamination occurred. The contamination of soil by the mixture of petrol and diesel fuel in a $20 \mathrm{ml} \mathrm{kg}^{-1}$ dose can contribute to limiting the growth of wheat and to decreasing its germinating capacity [29]. However, the authors analysed the growth and development of plants immediately after the contaminants were added. In the presented study, the investigation pertained to a long-time follow-up effect (i.e., after the passage of 4 years) of soil contamination. When analysing the presented data on wheat growth, one can note a permanent adverse effect of engine oil. The adverse effects of oils on cultivated plants can be explained by the negative effects of their hydrocarbons upon the processes of transpiration and respiration of plants, as well as on the transportation of nutrients through cellular membranes [30, 31]. Petrol contains a high proportion of volatile compounds that can rapidly evaporate from the soil and are also more vulnerable to natural biodegradation [32]; therefore, no negative effect of this substance upon the growth of winter wheat was observed in the experiment. Only a few pieces of information are available in literature on the effects of the application of bioremediation enhanced by microbiological preparation on PDS-contaminated soils and upon the growth of plants cultivated on those soils. Rusin et al. [21] demonstrated that such actions can positively affect the morphological features of broad bean plants growing in the soil contaminated by diesel fuel, increasing significantly the number and mass of shoots, as well as the number of seeds. The additions of compost, bentonite, calcium oxide [28, 33, 34], and bird droppings [35] applied as means to improve the state of soils contaminated by PDSs also contributed to the better growth and development of plants.

No significant effect of the studied PDSs upon the nitrogen content in wheat leaves was found (Table 2). Wyszkowski and Wyszkowska [36] demonstrated that engine oil applied in the dose of $9 \mathrm{~g} \mathrm{~kg}^{-1}$ results in the decreases in $\mathrm{N}$ content in the above-ground parts of oats and maize. The authors did not find this relationship after applying a lower dose of the xenobiotic. The decreases in nitrogen content in plants caused by the presence of PDSs in soil were also reported by other 
Table 2. Contents of nitrogen, carbon, and sulphur in winter wheat leaves $\left(\mathrm{g} \mathrm{kg}^{-1}\right)$.

\begin{tabular}{|c|c|c|c|}
\hline Treatments & $\mathrm{N}$ & $\mathrm{C}$ & $\mathrm{S}$ \\
\hline EO & $29.93^{\mathrm{a}^{\mathrm{a}}}$ & $402.05^{\mathrm{ab}}$ & $3.56^{\mathrm{c}}$ \\
\hline EOr & $30.10^{\mathrm{a}}$ & $407.48^{\mathrm{b}}$ & $3.15^{\mathrm{bc}}$ \\
\hline DF & $30.70^{\mathrm{a}}$ & $402.25^{\mathrm{ab}}$ & $2.50^{\mathrm{a}}$ \\
\hline DFr & $30.85^{\mathrm{a}}$ & $398.64^{\mathrm{a}}$ & $3.25^{\mathrm{bc}}$ \\
\hline P & $32.36^{\mathrm{ab}}$ & $407.25^{\mathrm{b}}$ & $2.67^{\mathrm{ab}}$ \\
\hline Pr & $29.93^{\mathrm{a}}$ & $400.97^{\mathrm{a}}$ & $2.80^{\mathrm{ab}}$ \\
\hline C & $31.98^{\mathrm{a}}$ & $396.93^{\mathrm{a}}$ & $3.16^{\mathrm{bc}}$ \\
\hline Cr & $35.07^{\mathrm{b}}$ & $401.62^{\mathrm{a}}$ & $4.96^{\mathrm{d}}$ \\
\hline
\end{tabular}

*Values marked by different letters are statistically different $(\alpha=0.05)$

authors $[37,38]$. The discrepancies that appeared there can result from the different plant species used in experiments, as well as from the length of time that passed from the instance of soil contamination. Under the effect of ZB-01 biopreparation, a significant increase in nitrogen concentration was observed, but only with regard to the wheat cultivated on control soil. In our earlier study [21], the biopreparation applied on the soil contaminated with engine oil or petrol, contributed to the increased nitrogen content in the tissues of broad beans.

The contamination of soil by petrol contributed to the increase in carbon content within the tissues of winter wheat, although applying enhanced bioremediation levelled those differences with regard to the control object. In general, PDSs contribute to the increase in carbon content in soil, a fact associated with their structure (they contain aliphatic hydrocarbons, cycloalkanes, olefins, and arenes) $[39,40]$. It can partly explain the increase in carbon content in plants growing on the soil contaminated by those substances. In turn, the sulphur content was evidently reduced under the effect of soil contamination by diesel fuel. The ZB-01 biopreparation applied on this soil as well as on control soil resulted in a significant increase in the sulphur content in plant leaves, thus levelling the $\mathrm{S}$ concentration in plants exposed to contamination with DF. Moubasher et al. [41] demonstrated that the petroleum-derived hydrocarbons can cause the increase in the sulphur content within roots and shoots of Bassia scoparia (L.); however, in the leaves of Vicia faba exposed to the contamination with engine oil, which is similar to the presented study, a decrease in sulphur content was found, again reduced by the application of enhanced bioremediation [21].

The content of magnesium in wheat leaves did not fluctuate significantly either under the effect of applied PDSs, or enhanced bioremediation (Table 3). A similar situation occurred in the case of calcium; however, here the ZB-01 preparation manifested different effects in the cases of different PDSs, i.e., it contributed to the increase in the content of the element in plants cultivated on diesel fuel-contaminated soil and in control plants, but it significantly reduced the $\mathrm{Ca}$ content in leaves of wheat cultivated on petrol-contaminated soil. Numerous authors indicated the possibility of the differentiated effect of PDSs upon the calcium and magnesium contents in plants, depending on the kind of contaminant, its dose, and on the species of the tested plant $[28,33$, 37]. Those substances can contribute to the increase, decrease, or they fail to cause changes in the content of analysed nutrients in plants. The soil contamination with petrol was conducive to the decreased iron content in the leaves of wheat cultivated on such soil. In turn, the enhanced bioremediation contributed to the decrease in Fe content in leaves of winter wheat cultivated on soil contaminated with engine oil and diesel fuel. Similarly, a significant decrease in the content of Fe was observed in the leaves of broad beans cultivated in soil contaminated with diesel fuel in the dose of $18 \mathrm{~g} \mathrm{~kg}^{-1}$ [38]; however, the dose of $9 \mathrm{~g} \mathrm{~kg}^{-1}$ did not produce such effects. The content of manganese increased clearly in the leaves of wheat cultivated on the soil contaminated with engine oil and diesel fuel, by approximately four and three times, respectively. In the case of engine oil-contaminated soil, bioremediation enhanced by ZB-01 preparation levelled those differences, whereas in the case of diesel fuel-contaminated soil it resulted in a further increase in the content of the element in plant tissues. Rusin et al. [38] demonstrated that the contamination of soil by diesel fuel in a $9 \mathrm{~g} \mathrm{~kg}^{-1}$ dose involves the increase in manganese content in the shoots and leaves of broad beans by $16 \%$ and $50 \%$, respectively, but no similar relationships were noted with regard to engine oil and petrol. In the cited studies, broad beans were cultivated immediately after the contamination of soil with PDSs. However, in other studies, where broad beans grew on the soil contaminated by the PDSs with a dose of $6 \mathrm{~g} \mathrm{~kg}^{-1}$ within three years after the instance of contamination, the observed level of manganese content was convergent with the values found in winter wheat, i.e., a significant increase was noted primarily under the conditions of soil contamination by oils, while biopreparation reduced the concentration of $\mathrm{Mn}$ only in the case of broad beans growing in soil contaminated by engine oil [21].

The literature provide little information pertaining to enhanced bioremediation on the content of nutrients in plants growing in soils contaminated by petroleumderived substances. Only Rusin et al. [21] demonstrated that it can decrease differences in the contents of nitrogen, carbon, and sulphur, between broad bean plants growing on contaminated soil and those cultivated on the control soil. Other techniques of soil remediation, e.g., the addition of compost, bentonite, or calcium oxide, demonstrate that the above actions can significantly modify the content of macro- and microcomponents in plants [28]. Many authors emphasise that the effectiveness of the bioremediation process 
Table 3. Contents of magnesium, calcium, iron, manganese, zinc, lead, cadmium, and copper in winter wheat leaves $\left(\mathrm{mg} \mathrm{kg}^{-1}\right)$.

\begin{tabular}{|c|c|c|c|c|c|c|c|c|}
\hline Treatments & $\mathrm{Mg}$ & $\mathrm{Ca}$ & $\mathrm{Fe}$ & $\mathrm{Mn}$ & $\mathrm{Zn}$ & $\mathrm{Pb}$ & $\mathrm{Cd}$ & $\mathrm{Cu}$ \\
\hline EO & $83.56^{\mathrm{ab}}$ & $2444.94^{\mathrm{b}}$ & $98.26^{\mathrm{e}}$ & $106.06^{\mathrm{c}}$ & $88.38^{\mathrm{e}}$ & $13.21^{\mathrm{c}}$ & $0.64^{\mathrm{bcd}}$ & $12.51^{\mathrm{c}}$ \\
\hline EOr & $99.53^{\mathrm{b}}$ & $2160.91^{\mathrm{b}}$ & $74.18^{\mathrm{abc}}$ & $52.16^{\mathrm{ab}}$ & $70.97^{\mathrm{d}}$ & $3.71^{\mathrm{a}}$ & $0.64^{\mathrm{bcd}}$ & $10.12^{\mathrm{ab}}$ \\
\hline $\mathrm{DF}$ & $81.92^{\mathrm{ab}}$ & $2490.60^{\mathrm{b}}$ & $80.63^{\mathrm{bcd}}$ & $64.72^{\mathrm{b}}$ & $49.27^{\mathrm{c}}$ & $2.25^{\mathrm{a}}$ & $0.41^{\mathrm{ab}}$ & $9.66^{\mathrm{a}}$ \\
\hline $\mathrm{DFr}$ & $94.45^{\mathrm{ab}}$ & $3105.84^{\mathrm{c}}$ & $63.78^{\mathrm{a}}$ & $115.49^{\mathrm{c}}$ & $48.82^{\mathrm{c}}$ & $2.93^{\mathrm{a}}$ & $0.90^{\mathrm{d}}$ & $11.88^{\mathrm{bc}}$ \\
\hline P & $73.03^{\mathrm{a}}$ & $2125.59^{\mathrm{b}}$ & $70.35^{\mathrm{ab}}$ & $27.29^{\mathrm{ab}}$ & $24.56^{\mathrm{a}}$ & $2.14^{\mathrm{a}}$ & $0.62^{\mathrm{bc}}$ & $10.10^{\mathrm{ab}}$ \\
\hline $\operatorname{Pr}$ & $81.50^{\mathrm{ab}}$ & $1093.88^{\mathrm{a}}$ & $82.84^{\mathrm{bcd}}$ & $39.83^{\mathrm{ab}}$ & $29.56^{\mathrm{ab}}$ & $7.33^{\mathrm{b}}$ & $0.76^{\mathrm{cd}}$ & $10.85^{\mathrm{abc}}$ \\
\hline $\mathrm{C}$ & $89.20^{\mathrm{ab}}$ & $2343.04^{\mathrm{b}}$ & $94.83^{\mathrm{de}}$ & $23.16^{\mathrm{a}}$ & $31.38^{\mathrm{ab}}$ & $1.64^{\mathrm{a}}$ & $0.24^{\mathrm{a}}$ & $9.02^{\mathrm{a}}$ \\
\hline $\mathrm{Cr}$ & $86.21^{\mathrm{ab}}$ & $3067.31^{\mathrm{c}}$ & $87.78^{\mathrm{cde}}$ & $34.86^{\mathrm{ab}}$ & $36.02^{\mathrm{b}}$ & $2.55^{\mathrm{a}}$ & $0.33^{\mathrm{a}}$ & $10.36^{\mathrm{ab}}$ \\
\hline
\end{tabular}

Symbols as in Table 1.

*Values marked by different letters are statistically different $(\alpha=0.05)$.

depends on many factors, such as soil humidity, temperature, $\mathrm{pH}$, and the bioavailability of substrates $[42,43]$.

The contents of the majority of heavy metals in the leaves of winter wheat increased under the effect of the studied PDSs (Table 3). The respective zinc contents in the tissues of plants cultivated on soil contaminated with engine oil and diesel fuel were nearly three times and one-and-a-half times higher than that in control plants. The ZB-01 preparation caused the reduction in the concentration of the metal in the object with soil contaminated by engine oil. The increase in zinc content in the leaves of broad bean plants in the presence of engine oil in soil was also demonstrated by Rusin et al. [21]; however, it did not exceed $15 \%$.

The lead content was approximately eight times higher in plants growing on engine oil-contaminated soil than in the control plants. Moreover, the enhanced bioremediation effectively reduced the $\mathrm{Pb}$ level to that found in the control plants. However, in the case of plants growing on the petrol-contaminated soil, the reaction to ZB-01 application was different, i.e., the $\mathrm{Pb}$ content increased approximately threefold. Rusin et al. [21] also demonstrated that the contamination of soil with engine oil, as well as with diesel fuel and petrol, resulted in a significant increase in the content of this heavy metal in the leaves of broad beans, with the highest content in the case of diesel fuel (the respective increases amounted to fourfold for DF, threefold for EO, and approx. twofold for P). For all of these PDSs, biopreparation reduced the concentration of $\mathrm{Pb}$ in the tissues of broad beans.

The cadmium content also evidently increased in the presence of engine oil and petrol in the substrate. In the case of this metal, the bioremediation either did not significantly affect its content (objects EO and P), or it caused an increase in the cadmium content in the leaves of winter wheat (object DF). Rusin et al. [21, 38] did not note the increase in cadmium content in the leaves of broad bean plants growing on soil contaminated by PDSs. Moreover, they even sometimes observed decreases in the content of this metal in the plant organs they analysed.

After four years, it was only the contamination of soil with engine oil that still showed the increased content of copper in the tissues of wheat. In this case, the ZB01 preparation somewhat reduced the concentration of that metal, while simultaneously increasing its level in the leaves of winter wheat growing in soil contaminated with diesel fuel. For the sake of comparison, the broad bean plants growing on soil contaminated earlier (three years before) with the same PDSs, had approximately three times higher levels of $\mathrm{Cu}$ than the broad bean growing in control soil [21].

There is only scarce information pertaining to the effect of enhanced bioremediation upon the content of heavy metals in the plants growing on soil contaminated by PDSs. Rusin e al. [21] demonstrated that such bioremediation is capable of levelling the differences in cadmium, lead, and zinc contents between broad bean plants growing in contaminated and control soils. This phenomenon results from the capability of microorganisms to adapt to adverse conditions and the ability to use harmful compounds for their own growth and development, which accelerates the rate of decomposition of the harmful compounds $[44,45]$.

\section{Conclusions}

1. In general, four years after the instance of soil contamination, the studied PDSs did not affected the growth of winter wheat, which is indicative of its relative resistance toward this kind of contaminant.

2. PDSs significantly modified the contents of some nutrients in plant leaves: soil contamination with diesel fuel resulted in the decrease in sulphur content, but contamination with petrol led to the increase in carbon content with a simultaneous decrease in iron content in the analysed organs of plants. Furthermore, oils contributed to the increase in the manganese content in plants. 
3. In general, the contaminants used in the experiments contributed to the increases in the contents of such heavy metals, i.e. zinc, lead, cadmium, and copper in the leaves of winter wheat; nevertheless, this phenomenon depended on the type of PDS, with stronger effects caused by oils.

4. The application of ZB-01 biopreparation on the soil contaminated with PDSs evoked changeable effects depending on the kind of contaminant and the analysed parameter, which generally resulted in levelling the negative effects of engine oil and diesel fuel.

\section{Acknowledgements}

Scientific publication financed by the Ministry of Science and Higher Education of the Republic of Poland.

\section{Conflict of Interest}

The authors declare no conflict of interest.

\section{References}

1. ALBERT E., TANEE F.B.G. A laboratory trial of bioaugmentation for removal of total petroleum hydrocarbon (TPH) in Niger Delta soil using Oscillatoria bornettia. J. Microbiol. Biotechnol. 1 (3), 147, 2011.

2. YEUNG C.W., LAW B.A., MILLIGAN T.G., LEE K., WHYTE L.G., GREER C.W. Analysis of bacterial diversity and metals in produced water, seawater and sediments from an offshore oil and gas production platform. Mar. Pollut. Bull. 62 (10) 2095, 2011.

3. JANBANDHU A., FULEKAR M.H. Biodegradation of phenanthrene using adapter microbial consortium isolated from petrochemical contaminated environment. J. Hazard Mater. 187 (1-3), 333, 2011.

4. SOUZA E.C., VESSONI-PENNA T.C., SOUZA O.R.P. Biosurfactant-enhanced hydrocarbon bioremediation: an overview. Int. Biodeter. Biodegr. 89, 88, 2014

5. GOSPODAREK J. Effect of oil derivative spill on epigeal mezofauna. Proc. ECOpole 2 (2), 309, 2008.

6. PÉREZ-LEBLIC M.I., TURMERO A., HERNANDEZ M., HERNANDEZ A.J., PASTOR J., BALL A.S., RODRIGUES J., ARIAS M. E. Influence of xenobiotic contaminants on landfill soil microbial activity and diversity. J. Environ Manage. 30, 1, 2010.

7. ZHAN X., WU W., ZHOU L., LIAN, J., JIANG T. Interactive effect of dissolved organic matter and phenanthrene on soil enzymatic activities. J. Environ. Sci. 22 (4), 607, 2010.

8. KACZYŃSKA G., BOROWIK A., WYSZKOWSKA J. Soil dehydrogenases as an indicator of contamination of the environment with petroleum products. Water Air Soil Pollut. 226, 372, 2015.

9. SHIRDAM R., ZAND A.D, BIDHENDI G.N, MEHRDADI N. Phytoremediation of hydrocarboncontaminated soils with emphasis on the effect of petroleum hydrocarbons on the growth of plant species. Phytoprotection 89 (1), 21, 2008.
10. GBADEBO A.M., ADENUGA M.D. Effect of crude oil on the emergence and growth of cowpea in two contrasting soil types from Abeokuta, Southwestern Nigeria. Asian J. Appl. Sci. 5, 232, 2012.

11. UJOWUNDU C.O., KALU F.N., NWAOGUIKPE R.N., KALU O.I., IHEJIRIKA C.E., NWOSUNJOKU E.C., OKECHUKWU R.I. Biochemical and physical characterization of diesel petroleum contaminated soil in southeastern Nigeria. Res. J. Chem. Sci. 1 (8), 57, 2011.

12. WYSZKOWSKI M., SIVITSKAYA V. Effect of different substances on some properties of soil contaminated with heating oil. J. Ecol. Eng. 16 (1), 62, 2015.

13. DINDAR E., ŞAĞBAN F.O.T., BAŞKAYA H.S. Bioremediation of petroleum contaminated soil. J. Biol. Environ. Sci. 7 (19), 39, 2013.

14. MILIĆ J.S., BEŠKOSKI V.P., ILIĆ M.V., ALI S.A.M., GOJGIĆ-CVIJOVIĆ G.Đ., VRVIĆ M.M. Bioremediation of soil heavily contaminated with crude oil and its products: composition of the microbial consortium. J. Serb. Chem. Soc. 74 (4), 455, 2009.

15. MILLIOLI V.S., SERVULO E.L.C., SOBRAL L.G.S., DE CARVALHO D.D. Bioremediation of crude oil-bearing soil: evaluating the effect of Rhamnolipid addition to soil toxicity and to crude oil biodegradation efficiency. Global NEST J. 11 (2), 181, 2009.

16. KARAMALIDIS A.K., EVANGELOU A.C., KARABIKA E., KOUKKOU A.I., DRAINAS C., VOUDRIAS E.A. Laboratory scale bioremediation of petroleumcontaminated soil by indigenous microorganisms and added Pseudomonas aeruginosa strain Spet. Bioresour. Technol. 101 (16), 6545, 2010.

17. THAPA B., KUMAR A.K.C., GHIMIRE A. A review on bioremediation of petroleum hydrocarbon contaminants in soil. Kathmandu University Journal of Science, Engineering and Technology 8 (1), 164, 2012.

18. PETRYSZAK P., KOŁOCZEK H., KASZYCKI P. Biological treatment of wastewaters generated by furniture industry. Part 1. Laboratory-scale process for biodegradation of recalcitrant xenobiotics. Ecol. Chem. Eng. A 15 (10), 1129, 2008.

19. KASZYCKI P., SUPEL P., PETRYSZAK P. Bacterial population dynamics of biostimulated auto- and allochthonous microflora in waste oily emulsions from the metal-processing industry. J. Ecol. Eng. 15 (3), 14, 2014.

20. GOSPODAREK J., PETRYSZAK P., KOLOCZEK H. The effect of the bioremediation of soil contaminated with petroleum derivatives on the occurrence of epigeic and edaphic fauna. Bioremediat. J. 20 (1), 38, 2016.

21. RUSIN M., GOSPODAREK J., NADGÓRSKA-SOCHA A. The effect of petroleum-derived substances on the growth and chemical composition of Vicia faba L. Pol. J. Environ. Stud. 24 (5), 2157, 2015.

22. AZCUE J., MURDOCH A. Comparison of different washing, ashing, and digestion methods for the analysis of trace elements in vegetation. Int. J. Environ. Chem. 57, 151,1994

23. NADGÓRSKA-SOCHA A., KAFEL A., KANDZIORACIUPA M., GOSPODAREK J., ZAWISZA-RASZKA A. Accumulation of heavy metals and antioxidant responses in Vicia faba plants grown on monometallic contaminated soil. Environ. Sci. Pollut. R. 20 (2), 1124, 2013.

24. LISTE H., FELGENTREU D. Crop growth, culturable bacteria and degradation of petrol hydrocarbons (PHCs) in a long-term contaminated field soil. Appl. Soil Ecol. 31, 43, 2006. 
25. NJOKU K.L., AKINOLA M.O., BUSARI T.O. Effect of time of application of spent oil on the growth and performance of maize (Zea mays). Afr. J. Environ. Sci. Technol. 6 (1), 67, 2012.

26. OSUAGWU A.N., OKIGBO A.U., EKPO I.A., CHUKWURAH P.N., AGBOR R.B. Effect of crude oil pollution on growth parameters, chlorophyll content and bulbils yield in air potato (Dioscorea bulbifera L.). Int. J. Appl. Sci. Technol. 3 (4), 37, 2013.

27. LOPES A., PIEDADE M.T.F. Experimental study on the survival of the water hyacinth (Eichhornia crassipes (Mart.) Solms - Pontederiaceae) under different oil doses and times of exposure. Environ. Sci. Pollut. Res. 21, 13503, 2014.

28. WYSZKOWSKI M., ZIÓŁKOWSKA A. Role of compost, bentonite and calcium oxide in restricting the effect of soil contamination with petrol and diesel oil on plants. Chemosphere 74 (6), 860, 2009.

29. HOUSHMANDFAR A., ASLI D.E. Seed germination and seedling growth of wheat, barley, alfalfa and clover as affected by gasoline and diesel fuel mixture. Adv. Environ. Biol. 5 (6), 1250, 2011.

30. PEZESHKI S.R., HESTER M.W., LIN Q., NYMAN J.A. The effects of oil spill and clean-up on dominant US Gulf coast marsh macrophytes. Environ. Pollut. 108, 129, 2000.

31. WAKE H. Oil refineries: A review of their ecological impacts on aquatic environment. Estuarine Coastal Shelf Sci. 62, 131, 2005.

32. SZARLIP P., STELMACH W., JAROMIN-GLEŃ K., BIEGANOWSKI A., BRZEZIŃSKA M., TREMBACZOWSKI A., HAŁAS S., ŁAGÓD G. Comparison of the dynamics of natural biodegradation of petrol and diesel oil in soil. Desalin. Water Treat. 52 (1921), 3690, 2014.

33. WYSZKOWSKI M., ZIÓŁKOWSKA A. Effect of compost, bentonite and calcium oxide on content of some macroelemennts in plants from soil contaminated by petrol and diesel oil. J. Elem. 14 (2), 405, 2009.

34. VOUILLAMOZ J., MILKE M.W. Effect of compost in phytoremediation of diesel-contaminated soils. Water Sci. Techn. 43 (2), 291-295, 2001.

35. OGBOGHODO I.A., EREBOR E.B., OSEMWOTA I.O., ISITEKHALE H.H. The effects of application of poultry manure to crude oil polluted soils on maize (Zea mays) growth and soil properties. Environ. Monit. Assess. 96 (1-3), 153, 2004.
36. WYSZKOWSKI M., WYSZKOWSKA J. Effect of enzymatic activity of diesel oil contaminated soil on the chemical composition of oat (Avena sativa L.) and maize (Zea mays L.). Plant Soil Environ., 51 (8), 360, 2005.

37. WYSZKOWSKI M., WYSZKOWSKA J., ZIÓŁKOWSKA A. Effect of soil contaminated with diesel oil on yellow lupine yoeld and macroelements content. Plant Soil Environ. 51 (8), 360, 2004.

38. RUSIN M., GOSPODAREK J., NADGÓRSKA-SOCHA A., BARCZYK G. Effect of petroleum-derived substances on life history traits of black bean aphid (Aphis fabae Scop.) and on the growth and chemical composition of broad bean. Ecotoxicology 26, 308, 2017.

39. RIFFALDI R., LEVI-MINZI R., CARDELLI R., PALUMBO S., SAVIOZZI A. Soil biological activities in monitoring the bioremediation of diesel oil-contaminated soil. Water Air Soil Pollut. 170 (1-4), 3, 2016.

40. WYSZKOWSKI M., SIVITSKAYA V. Changes in the content of organic carbon and available forms of macronutrients in soil under the influence of soil contamination with fuel oil and application of different substances. J. Elem. 17 (1), 139, 2012.

41. MOUBASHER H.A., HEGAZY A.K., MOHAMED N.H., MOUSTAFA Y.M., KABIEL H.F., HAMAD A.A. Phytoremediation of soils polluted with crude petroleum oil using Bassia scoparia and its associated rhizosphere microorganisms. Int. Biodeter. Biodegr. 98, 113, 2015.

42. YERUSHALMI L., ROCHELEAU S., CIMPOIA E., SARRAZIN M., SUNAHARA G., PEISAJOVICH A., LECLAIR G., GUIOT S. R. Enhanced biodegradation of petroleum hydrocarbons in contaminated soil. Biorem. J. 7 (1), 37, 2003.

43. DINDAR E., ŞAĞBAN F.O.T., BAŞKAYA H.S. Bioremediation of petroleum contaminated soil. J. Biol. Environ. Sci. 7 (19), 39, 2013.

44. NANEKAR S., DHOTE M., KASHYAP S., SINGH S.K., JUWARKAR A.A. Microbe assisted phytoremediation of oil sludge and role of amendments: a mesocosm study. Int. J. Environ. Sci. Technol. 12, 193, 2015.

45. MUKHERJEE A.K., BORDOLOI N.K. Bioremediation and reclamation of soil contaminated with petroleum oil hydrocarbons by exogenously seeded bacterial consortium: a pilot-scale study. Environ. Sci. Pollut. Res. 18, 471, 2011. 
